\title{
Development Of An Economic-Environmental Trade-Off Model For Industrial Land-Use Planning
}

\author{
R. M. Davis, G. S. Stacey, G. I. Nehman, F. K. Goodman*
}

\begin{abstract}
Few contemporary issues have received as much sustained attention as the deterioration of the quality of our natural environment and, particularly, the need to manage the trade-off between economic growth and the quality of that environment. This paper discusses research currently under way to develop a land-use methodology that will help planners address the trade-offs between environmental quality and economic development. The methodology is used to evaluate the social, economic, and environmental impact of alternative land-use plans. The methodology consists of a Regional Analysis Submodel and a Site Analysis Submodel. The first component is based on an expanded input-output analysis incorporating land use, resource inputs, and waste-emission outputs. The second component is an empirical analysis based on the specific suitability and compatibility of proposed land-use development packages. The land-use planning model developed is applied to a case-study area centered on Charleston, South Carolina.
\end{abstract}

\section{Introduction}

Recent concern for a healthy environment has stimulated passage of strong state and Federal legislation to control development. The National Environmental Policy Act of 1969, the Federal Water Pollution Control Act of 1972, and the Coastal Zone Management Act of 1972 are directed toward controlling the quality of the environment. Complementing this body of environmental law is the landuse legislation that has been before Congress for three years. While the Federal government has once again tabled land-use legislation, several state legislatures have taken the initiative. They are addressing the question of growth policy and are setting up the machinery for enforcing this policy. (For example, the States of Hawaii, Wisconsin, Maine, Massachusetts, and Vermont have recently passed comprehensive or partial land-use regulations.)

Growing attention is being given to the use of land-use regulations to control the state of the environment. This is a reversal of past policy that allowed development to occur in response to market factors only. This reversal by planners, state governments, and the public recognizes that development and environmental goals should be pursued in harmony. As stated in President Nixon's February 19, 1973, report on the State of Our Natural Resources:

*The authors are all associated with the Columbus Laboratories of the Battelle Memorial Institute. They are, respectively, Manager, Battelle Regional Centers Program; Staff Economist, Battelle Regional Centers Program; Research Economist, Land Use and Environmental Planning Section; and Information Scientist, Information Systems Section. 
"As we steadily bring our pollution problems under control more effective and sensible use of our land is rapidly emerging as among the highest of our priorities."

Effective land-use planning and control is a key to the protection and enhancement of our future environment.

\section{The Problem}

In the majority of planning districts and counties across the country, it is apparent that economic development and growth are still prime objectives. Basic community goals continue to be to provide jobs, quality education, health care, and other vital social services. These services are closely linked to the level of economic development in the region.

An industrial development program must be responsive to the following questions:

(1) What types of industries should we try to attract to the community?

(2) Where in the community should these industries be located?

(3) What will be the effects of these industries on community services, the economy, and the environment?

These questions are not new. However, today we are operating in a world with much greater concern for the effects, or impacts, of development. Sophisticated models and improved data are now available to the planner to measure effects and include this information in decision making.

\section{Recent Attempts at Model Development}

The study of economic development and its relationship to environmental quality has most frequently been approached by analyzing environmental considerations separately from economic considerations. Individual environmental factors such as air, water, and solid waste have also been treated separately from one another. As Ayres and Kneese noted "the partial equilibrium approach is both theoretically and empirically convenient, but ignores the possibility of important trade-offs between the various forms in which materials may be discharged back to the environment". ${ }^{1}$ Recent attempts at model development have recognized the limited value of this partial perspective. Isard analyzes the economic and ecologic linkages based on a linear flow model. The Isard model requires a detailed matrix of ecologic resource flows to describe all of the interrelated processes that take place within the ecosystem." Cumberland developed a model which adds rows and columns to the traditional input-output table to identify environmental benefits and costs associated with economic activity, and to distribute these costs by sectors. Leontief's general equilibrium model is an extension of his fundamental economic input-output formulation, in which the model assumes one additional sector in the basic input-output table. ${ }^{3}$ Pollution generated by the economy is consumed, at a cost, by an antipollution industry represented by this additional sector. 
An important modification of Leontief's approach was developed by Laurent and Hite. ${ }^{4}$ This model is composed of an interindustry matrix, a local use matrix, an export matrix and an ecological matrix. For each economic sector, it shows the physical environmental change in terms of natural resources consumed and pollutant emission rates per dollar of output. Laurent and Hite compute these effects by deriving the Leontief inverse of the interindustry matrix and multiplying the environmental matrices by that inverse. The remainder of this paper will discuss an extension of the Laurent-Hite approach to land-use planning.

\section{Formulation of the Land-Use Planning Model}

The land-use planning model developed here builds upon these earlier attempts. The model comprises two submodels that simulate the industrial-location decision process.

(1) The Regional Analysis Submodel evaluates the overall economic and environmental impact of locating an industry within a planning region.

(2) The Site Analysis Submodel evaluates the specific economic, environmental, and social impact of siting the industry within the planning space.

The model developed represents a two-step analysis: (1) a regional analysis based on an extended I/O table incorporating land-use and environmental factors in the table and (2) a site analysis designed to evaluate both the suitability and compatibility of alternative sites for proposed land-use changes.

\section{Development of Regional Analysis} Submodel (Submodel 1)

The Regional Analysis Submodel is based on a standard input-output table. The table was expanded to incorporate industrial land-use and natural-resource requirements as well as pollutant-waste characteristics of industry into the I/O table. The regional submodel may be viewed as a standard interindustry inputoutput matrix that has been supplemented with land-use, natural resource, and emission sectors where

$\mathrm{R}$.... Resource matrix specifying land and other resource requirements of each sector.

P .... Pollution matrix specifying the nonmarketed by-products of each sector.

A _.... Input-output table including resource and pollution sectors.

The Regional Analysis Submodel may be expressed as follows:

$$
\mathrm{A}=\mathrm{RP}(\mathrm{I}-\mathrm{A})^{-1} \text {. }
$$

Thus, one first calculates the Leontief inverse (I-A) ${ }^{-1}$ and postmultiplies the landuse, natural-resource, and pollutant matrix by the inverse: This calculation pre- 
sents the impact of proposed industrial-development on the land-use changes, natural-resource, and waste generation characteristics of the region.

Land-Use, Resource, and Waste-

Emission Data for Submodel 1

Reasonably good data are available for Submodel 1. An extensive survey of industrial land-use requirements was completed by the Bureau of Public Roads, U.S. Department of Transportation, in July $1970^{5}$, including (1) total land are $\mathrm{x}$, (2) floor space, (3) parking area, and (4) building-site area for each Standard Industrial Classification (SIC) category surveyed.

Land area per employee and floor area per employee are viewed as resource requirements. Several tentative conclusions, drawn from the survey, bear on the design of Submodel 1. They are as follows:

(1) "All area measures are a function of the size of the establishment measured in terms of number of employees...

(2) "Different industries or activities require differing amounts of area per employee...

(3) "Industry location and space utilization rates are a function of local environmental factors such as the density of the surrounding residential development, and the age of the surrounding development both residential and non-residential."

In addition, data were abstracted from field surveys completed by Battelle, as well as by Laurent and Hite ${ }^{7}$, Stepp ${ }^{8}$, Duprey ${ }^{9}$, and others on natural-resource usage and waste-disposal characteristics of firms. The data on land-use/naturalresource inputs and waste-emission characteristics were organized in matrix form as shown in Table 1. Specific information was collected to derive environmental coefficients for water and land input requirements; and air, water, and other pollutant output emissions. This data is based on best estimates of existing, in-place technology.

\section{Development of Site Analysis}

Submodel (Submodel 2)

The second component in the land-use-planning model is the site analysis submodel. The site analysis examines both the potential for development and the expected economic and environmental impacts from proposed industrial land-use changes. This methodology was developed by Dee, et al. The approach conducts the analysis at two levels: (1) suitability of the land and (2) compatibility with existing land uses. ${ }^{10,11}$

Site-Suitability Evaluation. In the past, suitability for development has generally been based on economic feasibility. This submodel, however, includes environmental and social parameters as well as economic. According to Dee, et al., "Suitability is defined as the degree to which natural and man-made qualities of the land are economically, socially, and environmentally suited for a particular use". ${ }^{10}$ 
TABLE 1. LAND-USE/NATURAL-RESOURCE INPUTS AND POLLUTION EMISSIONS BY SECTOR

\begin{tabular}{|c|c|}
\hline & $\overline{\mathbf{S I C}_{1} \ldots \ldots \ldots \mathrm{SIC}_{\mathbf{Z}}}$ \\
\hline  & $\begin{array}{l}\text { Total Land Area ( } \mathrm{ft}^{2} / \text { employee) } \\
\text { Floor Space ( } \mathrm{ft}^{2} / \mathrm{employee)} \\
\text { Parking Area }\left(\mathrm{ft}^{2} / \mathrm{employee}\right) \\
\text { Building Site Area ( } \mathrm{ft}^{2} / \text { employee) } \\
\text { Domestic Water (gals } / \$ \text { output) } \\
\text { Cooling Water (gals } / \$ \text { output) } \\
\text { Process Water (gals } / \$ \text { output) } \\
\text { Total Water (gals } / \$ \text { output) } \\
\text { - } \\
\text { - } \\
\text { - }\end{array}$ \\
\hline 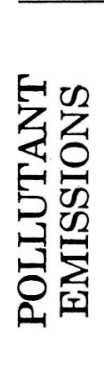 & $\begin{array}{l}\text { Particulates (lbs } / \$ \text { output) } \\
\text { Sulfur Dioxide (lbs } / \$ \text { output) } \\
\text { Water Discharge (gals } / \$ \text { output) } \\
\text { 5-Day BOD (lbs } \$ \text { output) } \\
\text { Solid Waste (cu yds } / \$ \text { output) } \\
\text { - } \\
\text { - } \\
\text { m }\end{array}$ \\
\hline
\end{tabular}

The environmental parameters describe (1) physical and chemical effects on the land, water, and air; (2) ecological effects on terrestrial and aquatic habitats; and (3) changes in the aesthetic character of a site. The social parameters describe the demographic distribution of labor and consumers who would be affected by the development. A list of all the parameters in the suitability evaluation is shown in Table 2.

The suitability of a given location for a specific land use is expressed by a numerical score ranging from 1 (low) to 7 (high). Objective and subjective scores were developed by a multidisciplinary team including economists, environmentalists, and social planners. For future applications, the system is conducive to including local citizens and interest groups in the land-use suitability ranking. Some illustrative rankings are shown in Figure 1. They are used to screen development proposals.

Land-Use Compatibility Evaluation. The compatibility evaluation was designed to help the planner group identify those activities that are compatible land uses and to separate those land uses that are not compatible. As defined by Dee et al., "Land use compatibility is the degree to which adjoining land uses reinforce desired economic, social, or environmental qualities of the natural and man-made en- 


\title{
TABLE 2. PARAMETERS USED IN LAND-USE SUITABILITY EVALUATION
}

\author{
Economic \\ - Soil limitations \\ - Salt water intrusion \\ - Topogràphy \\ - Transportation access \\ - Utilities \\ - Existing land use \\ - Vegetation \\ Environmental \\ - Ecology \\ - Productivity \\ - Physical displacement \\ - Pollution potential \\ - Water quality \\ - Air quality \\ - Soil erosion \\ - Aesthetics \\ - Scenic vistas \\ Social \\ - Commuting \\ - Community cohesion \\ - Community character
}

vironment. Existing land-use patterns, whether they generate condominium development or open space, will be affected either positively or negatively when changes in land uses are implemented. The following types of questions are addressed by the compatibility analysis:

- What happens when industry locates in a previously residential area?

- What happens when a freeway bisects a community?

- What happens when a school is located next to a freight terminal?"12

Once again, guidelines for environmental, social, and economic considerations have been developed. The environmental considerations closely parallel factors that are presently included in environmental impact assessments. These factors should guide the developer to choose sites that have low potential for environmental impact. This would save the developer the cost of mitigating impacts in environmentally sensitive areas and in investing in areas that eventually would prove infeasible to build in.

The value of land is considered for various uses in the economic compatibility evaluation. A low rating would be placed on a use of the land which would 
Resource Characteristics

\begin{tabular}{lll}
\hline & Rural: Mod- & Rural: Poor \\
$\begin{array}{l}\text { Urban: Good } \\
\text { soil and } \\
\text { access }\end{array}$ & $\begin{array}{l}\text { erate soil, } \\
\text { slope develop- } \\
\text { ment and access }\end{array}$ & $\begin{array}{l}\text { soil, low- } \\
\text { little and access }\end{array}$ \\
\hline
\end{tabular}

Type of Land Use*

$\begin{array}{lccc}\text { Residential } & 6 & 7 & 5 \\ \text { Commercial } & 7 & 4 & 2 \\ \text { Industrial } & 6 & 5 & 3 \\ \text { Agricultural } & 4 & 5 & 5 \\ \text { Recreational } & 5 & 6 & 7 \\ & \text { FIGURE } & \text { 1. } & \text { ECONOMIC SUITABILITY } \\ & & \text { RANKINGS DEVELOPED FOR } \\ & & \text { A RURAL COASTAL COM- } \\ & & \text { MUNITY-AN EXAMPLE }\end{array}$

*Shortened from the original list of 22 categories for this illustration.

decrease land values in the area (for example, locating heavy industry next to residential). However, a land use change that would increase the community's land values substantially would rank high (for example, locating residential next to open space).

"The social compatibility evaluation considered both access and safety factors. Safety refers to security, traffic safety, and freedom from industrial impingements such as noise and radiation. If the location of land uses did not increase hazards, it was rated high. The second social compatibility criterion was access, that is, the ease with which people could use community services. A land use was rated low on access if it created a barrier that would divide a community". ${ }^{14}$

A team of environmentalists, economists, and sociologists compared pairs of potential adjacent land uses and assigned numerical compatibility scores that ranged from 1 to 5 . These scores represented an aggregation of both objective and subjective judgments on a set of explicitly defined criteria. Higher scores indicate greater compatibility (Figure 2).

Both the land-use suitability and land-use compatibility evaluations were expressed in index form, with each element in the index weighted according to local preferences and goals.

\section{Model Application}

To test the land-use planning tool, the model was applied to a case study area that included the Charleston, South Carolina, metropolitan region. The region consists of three counties, Charleston, Dorchester, and Berkeley. Regional economic data published by the Water Resources Research Institute at Clemson, together 


\begin{tabular}{|c|c|c|c|c|c|}
\hline & Residential & Commercial & Industrial & Agricultural & $\begin{array}{c}\text { Recreation } \\
\text { Reserves }\end{array}$ \\
\hline Residential & $\begin{array}{l}\mathrm{ENV}=5 \\
\mathrm{ECO}=5 \\
\mathrm{SOC}=5\end{array}$ & & & & \\
\hline Commercial & $\begin{array}{l}\mathrm{ENV}=2 \\
\mathrm{ECO}=3 \\
\mathrm{SOC}=4\end{array}$ & $\begin{array}{l}\mathrm{ENV}=5 \\
\mathrm{ECO}=5 \\
\mathrm{SOC}=5\end{array}$ & & & \\
\hline Industrial & $\begin{array}{l}\mathrm{ENV}=2 \\
\mathrm{ECO}=2 \\
\mathrm{SOC}=3\end{array}$ & $\begin{array}{l}\mathrm{ENV}=4 \\
\mathrm{ECO}=3 \\
\mathrm{SOC}=4\end{array}$ & $\begin{array}{l}\mathrm{ENV}=5 \\
\mathrm{ECO}=5 \\
\mathrm{SOC}=5\end{array}$ & & \\
\hline Agricultural & $\begin{array}{l}\mathrm{ENV}=3 \\
\mathrm{ECO}=2 \\
\mathrm{SOC}=5\end{array}$ & $\begin{array}{l}\mathrm{ENV}=2 \\
\mathrm{ECO}=1 \\
\mathrm{SOC}=5\end{array}$ & $\begin{array}{l}\mathrm{ENV}=2 \\
\mathrm{ECO}=3 \\
\mathrm{SOC}=4\end{array}$ & $\begin{array}{l}\mathrm{ENV}=5 \\
\mathrm{ECO}=5 \\
\mathrm{SOC}=5\end{array}$ & \\
\hline $\begin{array}{r}\text { Recreation } \\
\text { Reserves }\end{array}$ & $\begin{array}{l}\mathrm{ENV}=2 \\
\mathrm{ECO}=4 \\
\mathrm{SOC}=5\end{array}$ & $\begin{array}{l}\mathrm{ENV}=1 \\
\mathrm{ECO}=3 \\
\mathrm{SOC}=4\end{array}$ & $\begin{array}{l}\mathrm{ENV}=1 \\
\mathrm{ECO}=1 \\
\mathrm{SOC}=5\end{array}$ & $\begin{array}{l}\mathrm{ENV}=2 \\
\mathrm{ECO}=4 \\
\mathrm{SOC}=5\end{array}$ & $\begin{array}{l}\mathrm{ENV}=5 \\
\mathrm{ECO}=5 \\
\mathrm{SOC}=5\end{array}$ \\
\hline & \multicolumn{5}{|c|}{$\begin{array}{l}\mathrm{ENV}=\text { Environmental compatibility } \mathrm{s} \\
\mathrm{ECO}=\text { Economic compatibility score } \\
\mathrm{SOC}=\text { Social compatibility score } \\
\text { Scores range from } 1 \text { (low) to } 5 \text { (high) }\end{array}$} \\
\hline FIGURE 2. & $\begin{array}{l}\text { DMPATIBI] } \\
\text { RURAL CO }\end{array}$ & $\begin{array}{l}\text { CY RANK } \\
\text { STAL CO }\end{array}$ & $\begin{array}{l}\text { GS DEVE } \\
\text { IUNITY }\end{array}$ & $\begin{array}{l}\text { OPED FO } \\
\text { AN EXAI }\end{array}$ & $L E^{15}$ \\
\hline
\end{tabular}

with the land-use and environmental surveys discussed above were particularly useful in testing the model. The model was loaded on a CDC 6400 computer and was programmed for remote terminal interaction through the NUCLEUS (Numeric Classification Evaluation System) programming language developed by Battelle.

\section{Regional Evaluation}

A regional input-output table was constructed that included land-use, naturalresources, and waste-emission sectors. The table included the 23 economic sectors shown in Figure 3. The regional table was derived from the national I/O table by adjusting the national coefficients according to location quotients computed from local employment levels. Two important additional assumptions were made in the model. First, it was assumed that one half of all new jobs created in the region would be filled by in-migrants, and, second, the average size of in-migrating families was assumed to be 3.5 persons/family. It was found that the model was sensitive to both ratios suggesting that it is important to have good data on these ratios. 
Sector

Ag., Forestry \& Fisheries

Food \& Kindred Products

Construction \& Mining

Textile \& Apparel Mfg.

Lumber \& Wood Prods. Mfg.

Sector Number

Furniture \& Fixture Mfg.

Printers \& Publishers

Chemical Manufacturing

Petroleum \& Coal Manufacturing

Rubber, Plastic \& Related Mfg.

Stone, Clay \& Glass Prods. Mfg. 11

Machinery, Repairs and Metal Shops

Miscellaneous Manufacturing $\quad 13$

Transportation 14

Communications 15

Utilities 16

Eating \& Drinking Places 17

Hotels \& Lodging Places 18

Gasoline Service Stations 19

Other Wholesale and Retail Trade 20

Finance \& Insurance $\quad 21$

Real Estate $\quad 22$

Other Business \& Personal 23

\section{FIGURE 3. SECTORS IN CHARLESTON REGION I/O TABLE}

To test the model, it was hypothesized that the Charleston region would choose between two different industrial-development proposals. In each case, the prospective industry represented 600 new jobs in the region. The Regional Submodel (Submodel 1) was run to evaluate the potential direct and indirect regional economic and environmental impact of locating a Cotton Finishing plant (2261) and a Fabricated Structural Steel plant (3441) in the region. A sample of the output from the Regional Submodel is shown in Table 3. The total impact evaluation takes the form of a with and without analysis in which the base run represents the economic and environmental conditions prior to locating the selected industries. The siting of an industry was simulated by increasing the employment and final demand vectors in the appropriate SIC sector and monitoring changes on economic factors, land-use, natural-resources, and waste-emission parameters.

The analysis indicates that the location of a Fabricated Structural Steel plant would create a total of 2,118 new jobs in the region (600 plus 1,518 additional) in Fabricated Steel and related sectors. This impact is some 74 more jobs than would have been created by locating the same size Cotton Finishing plant in the region. The total requirements for land area increased by 14.3 million $\left(\mathrm{ft}^{2}\right)$ and by 14.7 million $\left(\mathrm{ft}^{2}\right)$, respectively, when the Cotton Finishing plant or the Fabricated Steel plant was located in the region. 


\section{TABLE 3. TOTAL ECONOMIC AND ENVIRONMENTAL IMPACTS GENERATED BY ADDING 600 NEW EMPLOYEES - AN EXAMPLE}

\section{Cotton Finishing Plant}

(Sector 2261)

\section{ECONOMIC FACTORS}

Value Added by Industry

Employment Opportunity
Fabricated Structural Steel Plant (Sector 3441)

$\begin{array}{lrr}\text { LAND USE AND NATURAL RESOURCES } & \\ \text { Domestic Water (Gals) } & 291 & 317 \\ \text { Cooling Water (Gals) } & 4,771 & 8,235 \\ \text { Process Water (Gals) } & 15,023 & 11,979 \\ \text { Total Water Intake (Gals) } & 16,938 & 17,665 \\ \text { Land Area (Sq Ft) } & 14,300,350 & 14,728,435 \\ \text { Floor Space (Sq Ft) } & 1,073,721 & 1,173,006 \\ \text { Parking Area (Sq Ft) } & 1,291,594 & 1,622,903 \\ \text { Building Site (Sq Ft) } & 754,078 & 879,064 \\ \text { WASTE EMISSIONS } & & \\ \text { Particulates (Lbs) } & 2,710,845 & 4,166,001 \\ \text { Hydrocarbons (Lbs) } & 1,205,817 & 1,328,205 \\ \text { Sulfur Dioxide (Lbs) } & 147,225 & 164,735 \\ \text { Gaseous Fluoride (Lbs) } & 0 & 0 \\ \text { Hydrogen Sulfide (Lbs) } & 15,997 & 16,976 \\ \text { CO }{ }_{2} \text { (Lbs) } & 87,382 & 104,641 \\ \text { Aldehydes (Lbs) } & 3,481 & 3,861 \\ \text { NO (Lbs) } & 54,887 & 61,561 \\ \text { Discharge (Gals) } & 12,031 & 9,453 \\ \text { 5 Day BOD (Lbs) } & 1,395,944 & 1,023,066 \\ \text { Suspended Solids (Lbs) } & 930,809 & 592,683 \\ \text { Solid Waste (Cu Yds) } & 53,231 & 56,835\end{array}$

The impact analysis was further broken down to determine the land consumption and solid-waste-generation impact on each sector in the region (Table 4). Location of a cotton finishing plant would result in large land-consumption impact in Agriculture, Forestry \& Fisheries, Food \& Kindred Products, Textile \& Apparel Mfg., and Petroleum \& Coal Manufacturing; and large solid-wastegeneration impact in Food \& Kindred Products, Construction \& Mining, Textile \& Apparel Mfg., Lumber \& Wood Prods. Mfg., and Other Wholesale and Retail Trade.

The impacts vary with the level of economic activity as well. The model was run for several different employment levels, adding 100 new employees at a time to the appropriate sector. The results can be plotted to show the regional trade- 
TABLE 4. TOTAL DIRECT AND INDIRECT IMPACT GENERATED BY ADDING 600 NEW EMPLOYEES

\begin{tabular}{|c|c|c|c|c|}
\hline \multirow[b]{2}{*}{$\begin{array}{l}\text { Sector } \\
\text { Number }\end{array}$} & \multicolumn{2}{|c|}{ Land Consumption } & \multicolumn{2}{|c|}{ Solid Waste } \\
\hline & $\begin{array}{c}\text { Cotton Finishing, } \\
1000 \mathrm{ft}^{2}\end{array}$ & $\begin{array}{c}\text { Structural Steel. } \\
1000 \mathrm{ft} 2\end{array}$ & $\begin{array}{l}\text { Cotton Finishing, } \\
\text { lbs }\end{array}$ & $\begin{array}{c}\text { Structural Steel, } \\
\text { lbs }\end{array}$ \\
\hline 1 & $>4,567$ & $>4,236$ & 782 & 725 \\
\hline 2 & $>3,134$ & $>3,126$ & $>5,154$ & $>5,140$ \\
\hline 3 & 203 & 235 & $>2,244$ & $>2,524$ \\
\hline 4 & $>1,251$ & 355 & $>5,374$ & 1,525 \\
\hline 5 & 193 & 201 & $>23,592$ & $>24,595$ \\
\hline 6 & 21 & 23 & 528 & 573 \\
\hline 7 & 27 & 28 & 1,303 & 1,326 \\
\hline 8 & 369 & 341 & 1,053 & 973 \\
\hline 9 & $>1,565$ & $>1,646$ & 1,098 & 1,154 \\
\hline 10 & 65 & 90 & 235 & 322 \\
\hline 11 & 89 & 132 & 279 & 417 \\
\hline 12 & 497 & $>1,877$ & $>2,038$ & $>7,699$ \\
\hline 13 & 143 & 141 & 1,674 & 1,654 \\
\hline 14 & 611 & 671 & 404 & 444 \\
\hline 15 & 47 & 50 & 157 & 167 \\
\hline 16 & 247 & 265 & 1,427 & 1,533 \\
\hline 17 & 18 & 19 & 272 & 273 \\
\hline 18 & 20 & 20 & 238 & 240 \\
\hline 19 & 35 & 41 & 101 & 116 \\
\hline 20 & 330 & 338 & $>2,185$ & $>2,236$ \\
\hline 21 & 159 & 162 & 1,194 & 1,219 \\
\hline 22 & 55 & 56 & 267 & 275 \\
\hline \multirow[t]{2}{*}{23} & 647 & 676 & 1,632 & 1,703 \\
\hline & $\overline{14,293}$ & $\overline{14,729}$ & $\overline{53,231}$ & $\overline{56,833}$ \\
\hline
\end{tabular}

$>$ : Indicates those sectors which receive the most significant impacts generated by adding 600 new employees.

off between economic gain and environmental degradation. The relationship is linear at this point, but work is progressing to develop more accurate relationships between economic gain and land consumption, waste emissions, and other forms of environmental degradation. It is expected that as net economic gain increases in some industries, a threshold is reached beyond which continued increases in net economic gain results in proportionately greater net damages. For other industries, increases beyond the threshold result in proportionately less additional impact on the environment.

\section{Site Evaluation}

Having completed the regional analysis, the development planner can identify those industries that best meet the economic and environmental goals of his region. The planner next must evaluate the suitability and compatibility of 
available industrial sites for locating the industry. Thus, the economic, environmental, and social characteristics of the study region were analyzed and the information recorded on a series of map overlays. The map technique utilized is similar to that used by McHarg in selecting potential transportation planning routes. To demonstrate the technique, two economic and two environmental parameters were analyzed in the region (Figure 4). The land-development potential is limited by the drainage and soil conditions. The coastal lowlands and poorly drained inland swamps offer low potential for development or development at high cost. These areas are shown in dark shading. The transportation access characteristics of the region (roads, railroads, and waterway transport) are mapped on a second overlay. The major transportation-access corridors in the region are readily identified by the dark lines on the map. A composite of these economic factors was developed by superimposing the two overlays on a base map for the region to define areas of common intersection called economic resource units. Each resource unit defined by this procedure has similar economic characteristics.

A similar approach has taken to developing environmental resource units (Figure 5). Wildlife habitats were mapped according to their sensitivity to development. The dark areas are what many environmentalists call critical areas not to be considered for development. Next, the forest development potential in the region was mapped. The lighter regions are open forests or forests of poor quality that offer little resistance to development. The two environment maps were overlaid on a base map of the region to define areas called environmentalresource units. The examples illustrate only four characteristics for the study area, but a wide range of environmental, economic, and social characteristics can be displayed in much the same way using the overlay technique.

A suitability and compatibility index would be developed for each available site based on the data displayed on the overlays. The index is a weighted composite of the environmental, economic, and social suitability of the proposed industrial package at the development site. The comparative analysis between sites is displayed in graph form in Figure 6. The curves in this figure illustrate an example of the trade-off between the environmental damages and economic gains for Industry X. Environmental gain is the reduction in environmental damages while economic gain is indicated by the increase in the number of employees in Industry X. The trade-off index is computed as a composite of the suitability and compatibility indexes. Thus, the choice of the appropriate site may be made in a comparison with all of the available sites. From Figure 6 it can be seen that if 0 to 150 additional employees are expected (or desired) for the subject industry, Site 3 would be preferred. Similarly, Site 2 would be preferred for the employment range of 150 to 250, Site 4 for 250 to 350, and Site 1 for 350 or more.

Site 3 may be a downtown industrial park with limited capacity that would result in severe impacts as employment (plant size) rises above 150 persons. Alternatively, Site 1 may be on the periphery of a city and may result in proportionately greater environmental impact for locating low levels of activity. This site would become preferred if the activity level were to be quite high (above 350 persons) because it might be the only site with adequate capacity. 


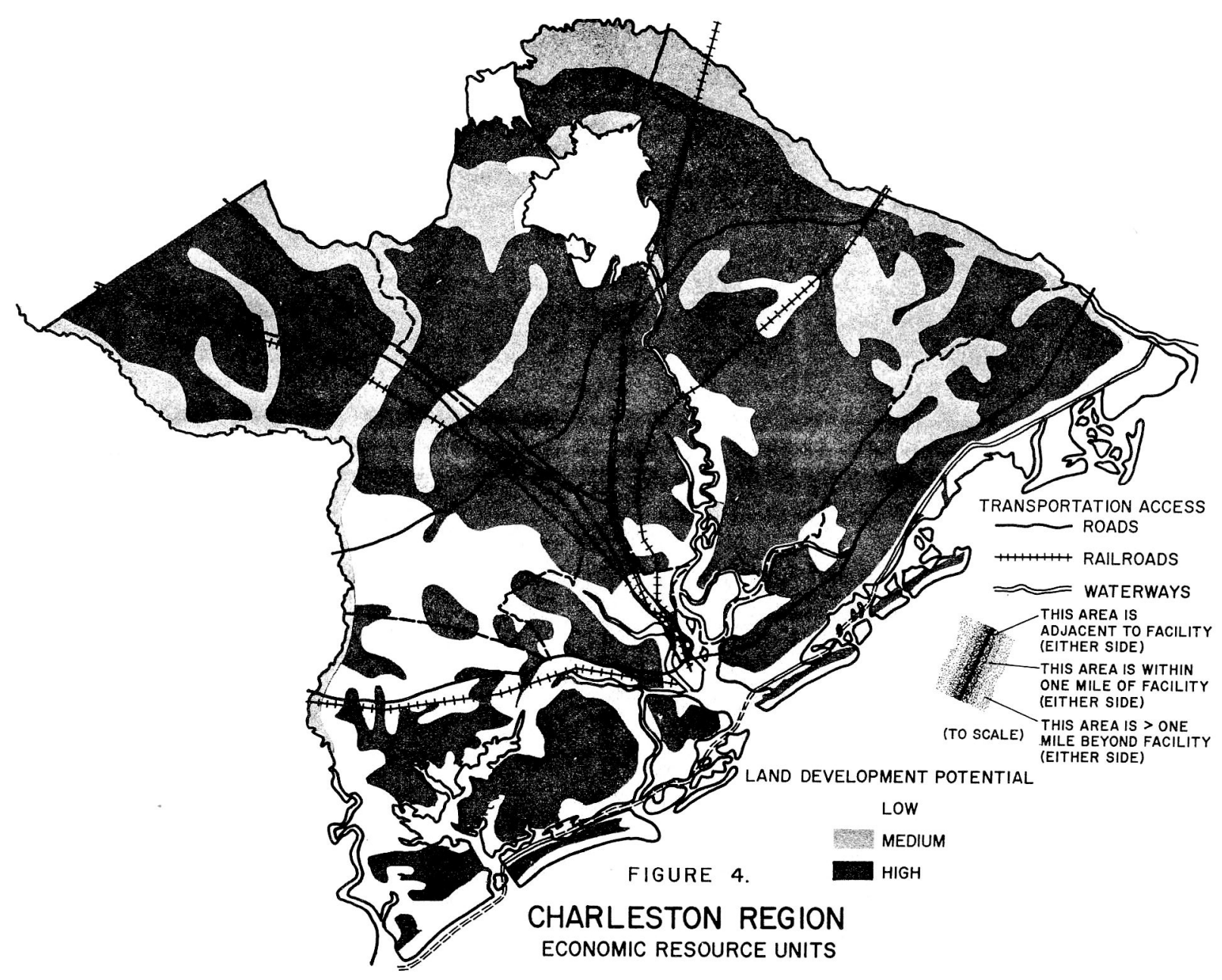




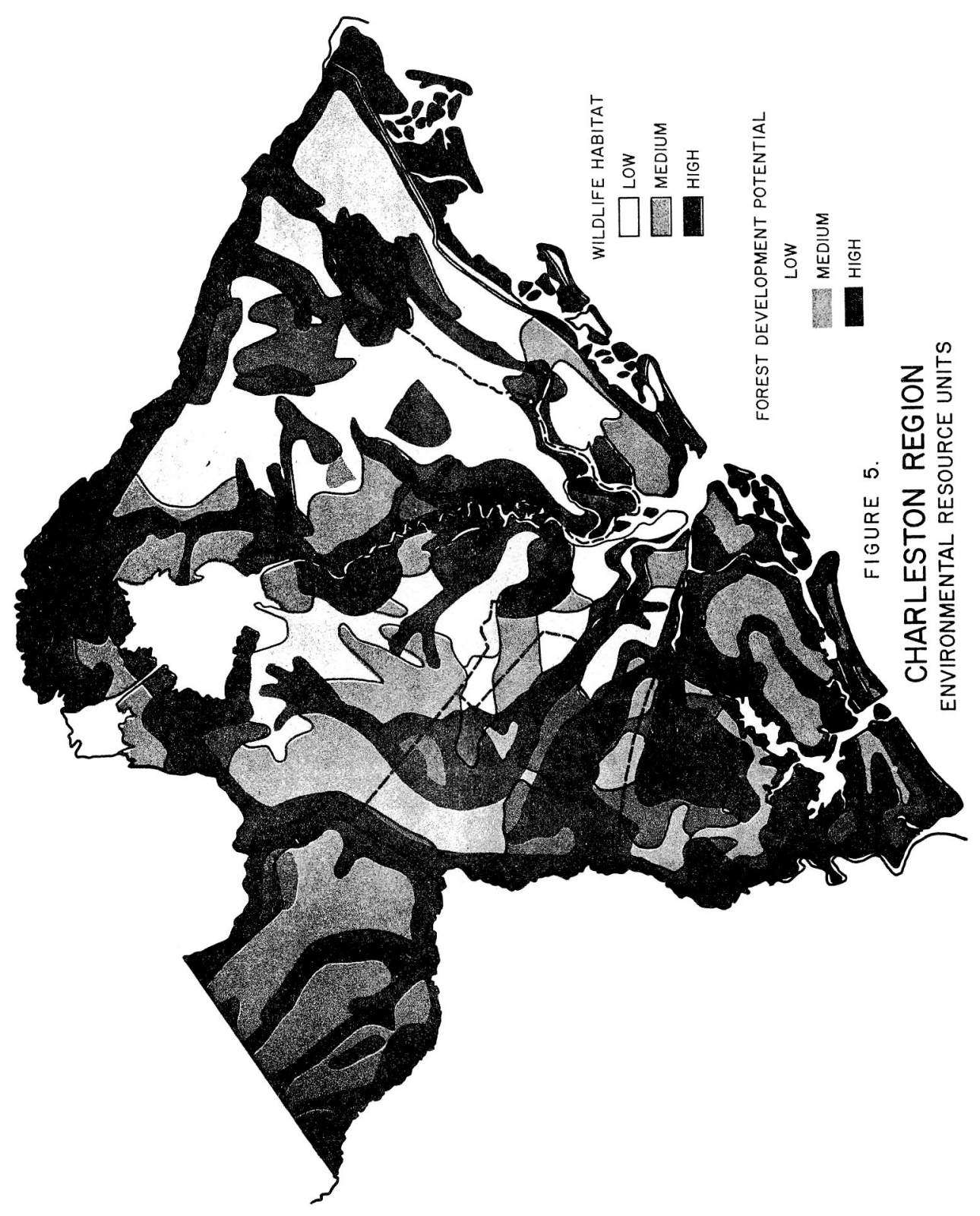




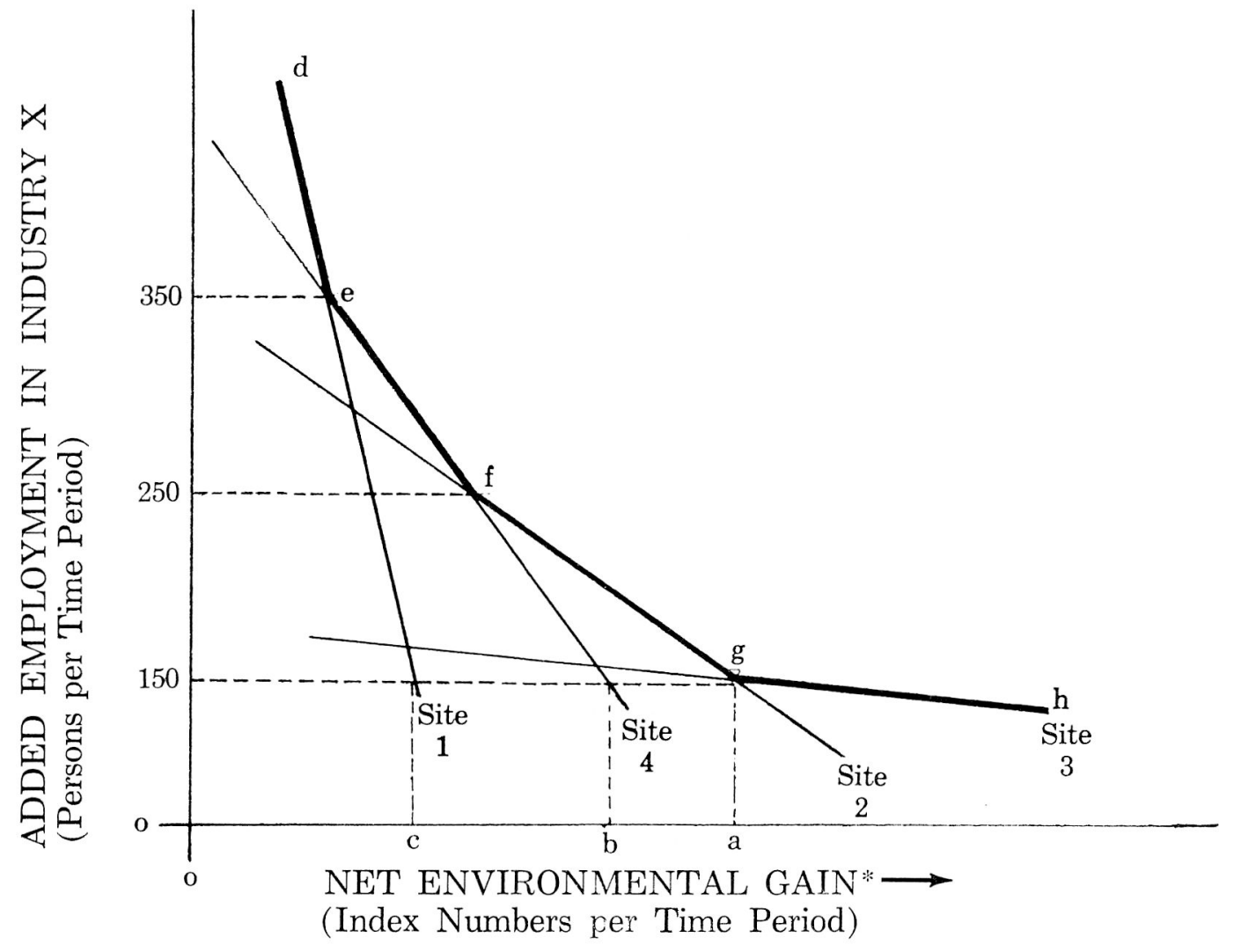

FIGURE 6. COMPARISON OF SITES FOR LOCATING CANDIDATE INDUSTRY $\mathrm{X}$

Finvironmental Gain is the inverse of environmental damages.

The additional environmental degradation experienced by locating at Site 4 rather than at Site 3 if the industry size is expected to be 150 employees is measured by (oa-ob). This graph provides a summary display of the results of the comparative site analysis. In addition, the curve (defgh) indicates the specific environmental-economic trade-off options faced by the subject region in deciding to locate an industry. The composite line illustrates the relationship between additional employment in the subject industry and environmental degradation in the subject counties.

\section{CONCLUSION}

The land-use planning model is designed to provide local administrators with a tool for evaluating the economic, environmental, and social impacts of locating industries in a planning region. In addition, it can be used to choose between alternative development sites. The output of the model is not to be a fixed land-use 
plan. Rather it is to be part of an ongoing land-use planning process. To develop the regional submodel from the national table, several simplifying assumptions were made. The result is a relatively simple generic approach to developing a regional model that can be used by local and state planners in formulating selective industrial-development programs.

\section{FOOTNOTES}

${ }_{1}^{1}$ Ayres, R. V., and A. V. Kneese. "Production, Consumption, and Externalities", American Economic Review, 59: 3-14, 1970.

2Isard, W. Ecologic-Economic Analysis for Regional Development, The Free Press, New York, 1972.

3Leontief, W. "Environmental Repercussions and the Economic Structure: An Input-Output Approach", A Challenge to Social Scientists, Shiegeto Tsuru, Ed., Asahi, Tokyo, 1970, pp. 114-134.

${ }^{4}$ Laurent, E. A. and J. C. Hite, Economic-Ecologic Analysis in the Charleston Metropolitan Region: An Input-Output Study, Water Resources Research Institute, Clemson University, April, 1971.

5Ide, E. A., Estimating Land and Floor Area Implicit in Employment-How Land and Floor Area Usage Rates Vary by Industry and Site Factors, U.S. Department of Transportation, July, 1970.

6Ibid., p. I-2.

7Laurent, E. A. and J. C. Hite, Op. cit.

8Stepp, J. M., Water Use, Waste Treatment, Water Pollution and Related Economic Data on South Carolina Manufacturing Plants, Clemson University, Water Resources Institute, Report No. 8, 1968.

9Duprey, J. M., Compilation of Air Pollutant Emission Factors, HEW National Air Pollution Control Administration, Durham, Publ. No. 999-AP-42, 1968.

10Dee, N., G. I. Nehman, J. M. Griffin, and M. L. Warner, "Land Use Planning: A Process Not a Plan", Paper presented at the Social Science Application Section, 44th Conference of Operations Research Society of America, San Diego, November, 1973.

11Griffin, J. M., N. Dee, R. King, and W. Diewald, New City Physical Design Methodologies, Battelle Memorial Institute, Columbus, December, 1973, pp. 39-46.

12Dee, N., et al., op. cit.

13Dee, N., et al., op. cit.

14Dee, N., et al., op. cit.

${ }_{15}$ Dee, N., et al., op. cit. 